\title{
THE RACISM PORTRAYED IN DJANGO UNCHAINED BY QUENTIN TARANTINO
}

\author{
Dewi Rahmawati Abd. Latif, LusianaDumbi \\ English Literature Department, Faculty of Cultural Science, \\ Muhammadiyah University ofGorontalo,
}

\begin{abstract}
Abstrak
The study is aimed to analyze Racism in Django Unchained by Quentin Tarantino usingsocio-psychological approach. The analysis used only three types of racism from five categories in Django Unchained, which are Blatant Racism, Cover Rasim, and Unintentional Racism and the impact of them in the character's psychological condition around environment. The method is qualitative method. Based on the research findings, it was found that there are five of racisms. They are getting after reading the scripts, watching the film and understanding precisely the Django Unchained movie.
\end{abstract}

Keywords: Racisms, Socio-Psychological Analysis.

\section{INTRODUCTION}

Racism is a global issue that never ends. From time to time, all forms of racism-related issues have beena negative impact on societies around the world, including in Indonesia.As understood that recognizes the superiority of a particular race over another race, racism isseen as a problem that not only comes from psychology or pathology individuals, but also from the pattern of cultural representation that is embedded withpractice, discourse, and the subjectivity of the West. (Barker, 2004)

Seeing racism as a pattern of cultural representations also comes from Western society that it is no wonder if racism is often displayed through the media masses like films, one of them is in a Hollywood movie. Film is a medium communication that can affect the audience, because simply by just watching the film, audience can be affected by what they see. Strength of reaching many social segments then make experts argue that the film has the potential to affect the audience. (Sobur, 2009) 
According to Danesi (2010) movie is a text that contains a series of photographic images which lead to the illusion of motion and action in real life. The film is also a form of development and advances in technology of photography and sound recordings. The film is able to grow imagination, tension, fear and emotional conflict audience, as they feel to be a part of the story of the film. The film also has advantages in terms of its ability to reach many people in a short time and is able to manipulate reality without losing credibility.

Audiences need to listen to the elements of ideology and propaganda which are veiled and implicit in many public relations phenomenon, a phenomenon that apparently does not depend on the presence or absence of civil liberties. Such a phenomenon may stem from a desire to reflect the condition of the community or may also come from a desire to manipulate (McQuail, 2003).

As in Indonesia, the United States is also a country with a diverse population that is very complex. Citing Tempo.com (January 16, 2013), a team of researchers from the University of Kansas conducted a survey research has consistently documented that there is discontent in race relations in the United States between majority and minority races. The study has been published in detail in the journal Psychological Science. They see social inequality as a major problem and see racism excess in an incident. Ignorance about the level of racism in history may explain why some people consider a racist thing in another way.

United States today is led by Barack Obama, who is president of the African-American to occupy the position as the 44th president of the United States. In fact, he was elected twice in the presidential elections held in 2008 and 2012, so he returned to the number one in the country of Uncle Sam.

An article reported that President Barack Obama took a stance in the fight against racism in the country during a speech at Morehouse College, Atlanta, USA. Obama said that the bitter past in the era of slavery has not disappeared, so that racism and discrimination still exist out there, so the community needs to deliberation. Ironically, the film about the tragedy of racism leverage slavery era 
with spiced violent spaghetti western style it is allowed to air, even gained two Oscars in 2013.

The Django Unchained (2012) tells of the era of slavery in the United States, where a slave managed to climb degree and become a hero of many criminals who kill whites to free her from slavery. This film clearly takes place mid 17 th century 5 before a civil war, a time when slavery used as a business. The film is the theme of the era of slavery in the United States has highlighted a difference through the twist in this movie where the main character is a black cowboy who at that time rarely found in the American South. The controversial film release in the United States in late 2012, and entered the Indonesian cinema at the beginning of 2013 is even still debated until mid-2013.

Citing news articles Tempo.com (January 18, 2013), the film Django Unchained film by Quentin Tarantino became the first film to win the highest income in the United States. No wonder the film with the theme of cowboy action and slavery is also eagerly awaited by all fans of the film in the world, including in Indonesia. Quentin Tarantino's own name is already familiar as a top Hollywood director famous for his eccentric.

Researcher chooses the Django Unchained film because of the controversial film that revived memories of the history of racism is precisely the community get two Oscars in 2013. The Oscar-winning film was a more attractive value for research, plus the film is very relevant for the discussion.

\section{RESEARCH METHOD}

This research is using a qualitative method. According to Djam'an and Komariah (2009) "Qualitative research thus refers to the meaning, concepts, definitions, characteristics, metaphors, symbols and description of things".

The researcher chooses qualitative in order to describe clearly about what is being focused on this research as a result. This research will be written systematically to ease the readers gaining information. 


\section{Research Approach}

In Introduction to Social Psychology, Social psychology is the scientific study of the way in which people's thoughts, feelings, and behaviors are influenced by the real or imagined presence of other people (Allport, 1985). One definition provided by Baron, et. al., (1989:6) about social psychology "the scientific field that seeks to understand the nature and causes of individual behavior in social situations".

(McLeod, 2007) reveals that Social psychologists therefore deal with the factors that lead us to behave in a given way in the presence of others, and look at the conditions under which certain behavior/actions and feelings occur. Social psychology is to do with the way these feelings, thoughts, beliefs, intentions and goals are constructed and how such psychological factors, in turn, influence our interactions with others.

The researcher uses socio-psychological approach to analyze the problem in the movie. Socio-psychological approach focuses on analyzing some types of racism in Django Unchained. Basically, this approach is used to reveal the problems inside the character's psychological condition around environment.

\section{Source of the Data}

The sources of the data in research are taken from Django Unchained movie directed by Quentin Tarantino. The data is in form words or all off utterances from transcripts. Also, this study uses some references from internet like journal or article as the supporting resources of the data.

\section{Technique of Collecting Data}

There are some steps that research do to collect the data. The first, the researcher watches the movie several times. The researcher watches the movie to know the entire story that describes about the impacts of racism and the last step is identifying them that the researcher found into its categories.

\section{Technique of Data Analysis}

In data analysis, this study used content analysis and data analysis about theory of Yamato (1991). Content analysis is "any technique for making inferences by systematically and objectively identifying special characteristics of 
messages" Holsti, 1968, p. 608 (as cited in Zhang \&Wildemuth) Three step analyses are identification, classification and interpretation.

\section{Identification}

The first step in this analysis is the researcher identifies the data. There is a data from the movie and other book which has the correlation to this analysis. The researcher watches the movie, matches the sentence and the situation that the writer sees in the movie with the script or subtitle by browsing, and then finds out the types of racism along with the impact of it in the movie.

\section{Classification}

After identifying the data, the next step is classifying it. In this step, after watching the movie and finding out data of the racism in the movie, this study classifies which scene that contains the impacts of racism. And then this study makes a corpus to classify the data based on types of racism and impact of racism in analysis.

\section{Interpretation}

This is the last step of technique of data analysis. After the researcher classifies the data, the researcher starts to data analysis one by one by using theory of Yamato (1991) about the types of racism. And the last, this study conclusion and suggestion is about the researcher's analysis.

\section{RESEARCH FINDINGS AND DISCUSSIONS}

\section{Finding}

The data finding explains about five types of racism in Django Unchained which was explained on the chapter II. Also, the research will explain the impact of racism in Django Unchained. These types of racism are Aware/Blatant Racism, Aware/Covert Racism, Unintentional Racism, Self-righteous Racism, and Internalized Racism. But the researcher will provide only 3 types which are Blatant Racism, Cover Racism, and Unintentional Racism. These three types will be provided as follow. 


\section{Racism That Occur in Django Unchained}

\section{Aware / Blatant racist:}

Data 1 : "Hello, poor devils."

(Act.00:05:16 $\rightarrow 00: 05: 18$ )

The statement above is expressed by Dr. King Schultz and the place was taken in the forest when he met the two men with Django and other black people. His statement is aimed to the black people without an apology even though he is such a wise man.

Data 2: "Nigger, don't you touch my brother's coat" (Act.00:09:45 $\rightarrow 00: 09: 50$ )

The statement above is expressed by one of the Speck brothers in the forest as Schultz asks Django to take the dead Speck brother's coat to put on. His statement is aimed towards Django. He said nigga because Django is a black guy and it is totally blatant of his saying such words without an apology or confusion. Data 3: "It's against the law for niggers to ride horses in this territory". (Act.00:28:29 $\rightarrow 00: 28: 33$ )

The statement above is expressed by Big Daddy as known as Mr. Bennett. The place was taken in his house when Django and Schultz arrived with their horses. The utterance of Big Daddy showed that he cannot agree with black people riding a horse and he said that without saying sorry or feeling guilty. He blatantly did it. He said that because he did not want to see a black person on a horse at least on his property surrounded by other black people.

Data 4: "(gasping) Whoa, whoa, whoa, whoa ... what the hell you think you're doing, boy? Get that nigger outta here!"

(Act.00:14:10 $\rightarrow 00: 14: 47$ )

The statement above is expressed by the innkeeper when Shultz and Django enter the salon for two glasses of beer. The statement was aimed towards Schultz to get Django, the black guy, out of the salon. This expression is rude and he said that without any guilty feeling. It is clearly that the innkeeper does not let 
black people to be inside his salon because black people do not deserve to be treated nice.

Covert Racism

\section{Data 5:}

(everyone is staring at Django and Dr. King Schultz when they are passing by) (Act.00:12:48 $\rightarrow 00: 14: 00)$

The act above is taken on the road in Bill Sharp's town when Django and Dr. King Schultz are passing by. Everyone gets shocked seeing Django on a horse. As they know, black persons do not deserve to ride on horses like they have not seen it before. This is a covert racist when racists are being racist with words left unsaid.

Data 6: (The two men forcibly dragged Broomhilda in the room without saying anything)

(Act. 02:31:17 $\rightarrow 02: 31: 34$ )

The act above is taken in a house showing that these two men were doing the covert racism by dragging Broomhilda in the room with no words said. They just did it.

Unintentional Racism

Data 7 :

Schultz: Oh, maybe while we discuss business, you could provide one of your loveliest black creatures to escort Django here around your magnificent grounds

Mr. Bennet : Oh, well absolutely! Uh, Betina sugar?

Betina : Yessir, Big Daddy?

Mr. Bennet : Could you take Django around

Betina :Yes'm?

Mr. Bennet : Django isn't a slave. Django is a free man, you understand? You can't treat him like any of the other niggers around here cause he ain't like any of the other niggers around here. You got it?

Betina : You want I should treat him like white folks? 
Mr. Bennet : No, that's not what I said.

Betina : Then I don't know what you want, Big Daddy.

Mr. Bennet : Yes, I can see that. Uh..( turn aside and hand gestures at a black woman behind him) What's the name of the peckerwood boy from town that works with the glass? His mama work over at the lumberyard.

Black woman : Oh you mean Jerry?

Mr. Bennet : That's the boy's name. Jerry! You know Jerry, don't you sugar?

Betina : Yes'm, Big Daddy.

Mr. Bennet : Well that's it then. You just treat him like you would Jerry.

(Act.00:30:41 $\rightarrow 00: 31: 37$ )

The dialog above occurs between Mr. Bennet and Betina as Betina is about to take Django around to see all the pretty stuffs when Schultz reminds Mr. Bennet that Django is a free man. He cannot be treated like a slave and must be treated as an extension of Schultz. Schultz seems to be nice but Mr. Bennet is nice just because Schultz does not want him to treat Django like a slave. And when Betina asks him about treating him like white people, Mr. Bennet says that it is not what he said. Betina should treat Django like a renowned person but still a black person.

\section{The Impact of Racism Towards Main Character}

(After Dr. King Schultz died, Django shot almost all the Candy land's people but he failed when his wife, Broomhilda was about to be shot right in the head by one of Calvin's toilers. Django surrendered and gave himself up them. So then they treated him like a slave and even worse while Broomhilda got locked in a room. They sold Django to the LeQuint Dickey Mining. When Django was on the way with the some toilers to LeQuint Dickey Mining, they stopped for a rest and there Django started to trick them. A couple of minutes later, they successfully got tricked by Django and when they gave Django a gun, he shot them off and got back to Candyland to rescue his wife. After he arrived, he waited for Calvin's other toilers who were still alive along with Calvin's sister and shot them off too 
without mercy. He let the black fellow be, except Steve. After made a little conversation with Steve, he shot him off and burned up Calvin's house.)

(Act. 02:11:33 $\rightarrow 02: 40: 40$ )

\section{Discussion}

Django Unchained is a movie that shows a lot of racist actions which also clearly shows that black people are lower than white ones. There are some actions or scenes that we can divide them into three types of racism, blatant, covert, and unintentional racism. Also there is an impact of racism that the researcher will show.

\section{Racism in Django Unchained}

\section{Aware / Blutant Racism}

Aware/blatant racism is the racism that is clear and unapologetically expressed and identified by both its victims and onlookers (Yamato, 1991). This type occurs in the movie.

For example utterance: (Act.00:05:16 $\rightarrow$ 00:05:18).

This statement expressed by Dr. King Schultz explaining that he is blatantly being racist towards Django and other blacks. He knows it is an offence and so do Django and other blacks. He is being racist without an apology. Calling black people poor devils is called racism too since Schultz is white. Schultz actually wants to treat them nice but he just has to pretend to be so in front of the Speck brothers because they are doing racism towards Django and his black friends.

For example utterance: (Act.00:09:45 $\rightarrow$ 00:09:50).

This statement is expressed by one of the Speck brothers. It was aimed to Django when Django was being asked by Dr. King Schultz to take his dead brother's coat. This is a blatant racism because he did it without thinking that Django would be offended or the impact he would get as a payback by saying that. He said that because the one Dr. King Schultz killed was his own brother. Besides, his leg got laid by the horse that Dr.King Schultz shot. For example utterance: (Act.00:28:29 $\rightarrow 00: 28: 33$ ). 
This statement is expressed by Mr. Bennet as known as Big Daddy. Mr. Bennet is actually a nice man but he never saw a black person on a horse. So he said that to Django when Django and Dr. King Schultz arrived at his house. He did it blatantly without saying sorry or apology over what he did because at that time, black people are lower and the white ones can do everything to them and also, Django and Dr. King Schultz is on his property surrounded by black people. For example utterance: (Act.00:14:10 $\rightarrow 00: 14: 47)$.

This statement is expressed by the innkeeper when Django and Dr. King Schultz came in to the salon for beers. This innkeeper at first did not see Django because he was fixing the light bulb. Even though he said he would make them some breakfast but after he turned around and saw Django, a black person, in his saloon then he spontaneously blatantly shouted without thinking that it was very rude of him, asking Django to get out of his saloon because he never saw any black person in his saloon. He did it without an apology or confusion.

\section{Aware/Covert Racism}

Aware/Covert Racism is when racists are being racist but just not saying it. For instance, upon seeing that a potential tenant is Indian, rather than saying it directly, a landlord will pull the apartment "off the market" without providing an explanation (Yamato:1991). This means someone is being racist to someone who are different from his group or race without saying anything and being racist through his action. As what occurs in Django Unchained, there are two parts showing covert racism.

For example utterance:

(Act. 02:31:17 $\rightarrow 02: 31: 34$ ).

This happened when everyone starred at Dr. King Schultz and Django as they passed by. Everyone in that town got shocked like they could not believe what they saw. A black riding a horse is unbelievable for them because they thought black people did not deserve to be treated that way. They had never seen this before. They were being racist just by starring at Django with that shocked 
look. This means white people cannot be united with black people especially when a black one is in the parallel position the way they are.

For example utterance:

(Act. 02:31:17 $\rightarrow 02: 31: 34$ ).

This is one of the aware/covert racism actions in this movie when two men dragged Broomhilda into the room. The room looked like the one they used to kidnap or do the slavery sex. This can be a racism too since they are white and Broomhilda is black. Broomhilda got dragged because her husband, Django tried to kill the white people in Candy land but he failed. These two men dragged Broomhilda because they wanted to hide her from Django and kept her away from him over what Django did to their white friends.

\section{Unaware / Unintentional Racism}

"With the best of intentions, the best of educations, and the greatest generosity of heart, whites, operating on the misinformation fed to them from day one, will behave in ways that are racist, will perpetuate racism by being 'nice' the way we're taught to be nice" (Yamato:1991). This is how the unintentional racism to be. Everyone has been taught to be nice to others and they can learn it from their parents who teach them to be and of course most of educated persons are taught to be nice and have a good attitude towards others who are from other race or different group or ethnic. But, we are still human beings. We do mistakes like we unintentionally hurt other people although we do not mean to. This also occurs in Django Unchained.

For example utterance: (Act.00:30:41 $\rightarrow 00: 31: 37$ ).

Mr. Bennet and Dr. King Schultz are both nice persons. Mr. Bennet is nice to black persons who he thinks are special. So it means he is not nice towards unspecial black people especially when they make a mistake like breaking a glass or not doing their job as he wants. Dr. King Schultz is a nice person and against slavery. He buys Django in order to give him freedom. He does not want anyone to treat Django like a slave. So when he was entering Mr. Bennet's house, he asked Mr. Bennet to take Django around to see beautiful stuffs with one of his 
slave. But he reminds him to treat Django nicely. And there Mr. Bennet goes, asking one of his slaves to do so.

Dr. King Schultz is unintentionally racist towards Django because he treats him way too nice that he does not want to hurt Django's feelings. As Yamato says, this type of racism comes from feeling guilty about the past. So Dr. King Schultz is apparently feeling guilty if he does not treat Django in a nice way. Even though he looks at it as being nice but it still a form of racism since he is white and Django is black. So basically, being too nice to a person who is from different race is racism too. Django might be going to assume that just because Schultz is white, Schultz just has to make up things by being overly nice towards him.

\section{The Impact of Racism Towards Main Character}

Django is one of the main characters in this movie. The movie contains an impact of racism itself towards him. Of course either bad or good things can give an impact. Like when you win a lottery or just successfully get your things done and that is a good thing and good thing causes you to feel like you are flying in the sky or some other things like that. But when bad things happen to you, you feel like that you are in the bad luck than can make you feel like to jump off from the top of the building or whatsoever that makes you want to just die. It is stressful indeed especially when a particular person tries to take the one you love away from you after suffering from so much pain.

"Racism can isolate and exclude people and groups, preventing them from having equal opportunities to education, employment and services. It can also prevent social and community connectedness, resulting in increased distrust, fear and resentment."

The statement above was revealed by Brook. As the fear and resentment Django feels is making him to take a revenge to the white people. He was being a slave getting tortured by white people and they sold his wife, Broomhilda (Hildi) to other whites. When they were together working as slaves, she got whipped in her back for doing a mistake. Django was begging their masters to stop it. He fell on his knees. But that did not make anything better. And when Dr. King Schultz 
bought him and set him free and made him as a partner as a bounty hunter, he had to lost him as well as they were about to get Hildi back.

He could not take it anymore. He had to make a revenge to kill all the white people in Candyland along with Steve, the black old guy who worked for Calvin but tortured his wife as well. The fear of losing his wife is haunting him and the loss of his that Dr. King Schultz had to die that way for rescuing his wife. So he shot them off and burned the house.

\section{CONCLUSION AND SUGGESTION}

\section{Conclusion}

In Django Unchained, a movie directed by Quentin Tarantino is indeed talking about racism. There are three types of racism the researcher found in the movie; Aware / Blatant, Racism, Aware / Covert Racism, and Unaware / Unintentional Racism. The racism in this movie is divided into seven datas and one is the impact of racism in the movie.

In addition, the racism in Django Unchained is the worst that ever shown in movie. They make slavery trade, torture black people, servitude, and other racist things. They have no respect towards others who are from different race.

\section{Suggestion}

To increaseour literature comprehension, this research should be a reference to learning process especially in literature. This research can give advantages to make the readers understand both of the types and the impact of racism, to give information to the students of English Literature about analyzing racism and to give a reference to teaching and learning process that related with this study. It is also used to give a profitable description to any further study who wants to study the same case, so this study will be a helpful information and useful reference for the next study.

Moral of the story in Django Unchained movie is we are all human beings. We have to treat each other like what it is supposed to be without looking down on each other because we are all equal even though we all know everyone has a 
different taste, or even though we are from different races, colors, and cultures. We are taught to respect each other.

After analyzing the types of racism and impact of itself towards the main character, the researcher realizes that there is another interesting problem in this movie to dig like what if Leonardo DiCaprio is actually a good man who just wants to take care of black people and Dr. King Schultz is actually an antagonist who does not actually set Django free but just he does it on purpose in order to help him become a bounty hunter.

\section{REFERENCES}

Allport, A. (1985). The historicalbackground of s ocial psychology. In

G. Lindzey\& E. Aronson (Eds.Handbook of social psychology (Vol. 1, rd ed., pp. 1-46). New York: Random House.

Allport, G. W. (1954). The Nature of Prejudice. Reading, MA: Addison-Wesley.

Barker, C. 2004. The SAGE Dictionary of Cultural Studies, London: SAGE Publications

Baron, R. A., Byrne, D., \&Suls, J.9). Attitudes: Evaluating the social world. Baron et al, Social Psychology. 3rd edn. MA: Allynand Bacon, 79-101.

Brook, A. (April, Wednesday $1^{\text {st }}$ 2015). Proposed amendments to the Racial Discrimination Act 1975. St. Kingstom

http://www.relationships.org.au/corporate-centre/submissions-and-policy statements/proposed-amendments-to-the-racial-discrimination-act-1975submission-to-the-exposure-draft

Danesi, Marcel. 2010. Pengantar MemahamiSemiotika Media. Yogyakarta: Jalan Sutra Djam'an\&Komariah.(2009). Metodepenelitiankualitatif.Bandung: Alfabeta

Ebert, R. (2013). Faster, Quentin! Thrill! Thrill!. Chicago

http://www.rogerebert.com/rogers-journal/faster-quentin-thrill-thrill

Edelstein, D. (2012). Django Unchained Is Manna for Mayhem Mavens. New York: New York Media, LLC.

Festinger, L., Schachter, S., \& Back, K. (1950). Social processes ininformal groups.

BRITISH, Jurnal Bahasa dan Sastra Inggris 
Fiske, J. 2004. Cultural and Communication Studies SebuahPengantarPaling Komprehensif. Yogyakarta: Jalasutra.

Geneva. (2001). International Migration, Racism, Discrimination and Xenophobia.Swizerland: International Labour Office (ILO).Hoyt, C. (2010). The Pedagogy of the Meaning of Racism: Reconciling a Discordant Discourse. Andover: Phillips Academy.

Jacobs, Christopher P. (2013) Film Theory and Approaches to Criticism, or WhatDid That Movie Mean?McCarty, T. (2012).

Christoph Waltz, Jamie Foxx, And

Leonardo DiCaprioStaIn Quentin Tarantino's Revenge Saga Mostly Set In The Deep South Just Before The Civil War. Los Angeles, CA: The Hollywood Reporter

McLeod, Saul (2007). Social Psychology http://www.simplypsychology.org/social-psychology.html

McQuail, S., Mooney, A., Cameron, C., Candappa, M., Moss, P. and Petrie, P.(2003) Early

Years and Childcare International Evidence Project. London: Thomas Coram Research Unit, Institute of Education.

Monaco, J. (1984). American Film Now: The People, The Power, The Money, The Movies. Landmark: New York Zoetrope.

Nittle, N.K. (2012). What Is Racism?. California: Occidental College

Prawitasari, M Y. (2010).Rasisme Dalam Film Tinkerbell: Studi SemiotikaTerhadapIsuRasismedalam Film Tinkerbell. Yogyakarta: Universitas Atma Jaya

Riyana, C. (2010). Media PembelajaranHakikat, Pengembangan,Pemanfaatan, danPenilaian. Bandung: CV Wacana Prima.

Shinta, Y. K. (2010). Anti Rasisme PadaTokoh Erin Gruwell Dalam Film Freedom Writers

Karya Richard Lagravense. Semarang: Universitas Diponegoro

Sobur, A. (2009). Semiotika komunikasi. Bandung: PT. RemajaRosdakarya

Wellman, DT. (2001). Portraits of White Racism. Melbourne: The University ofCambridge

Yamato, G. (1991). Something About The Subject Makes It Hard To Name. NY:Thomson/Wadsworth Pub. 